ADAM PUTKO (D) orcid 0000-0001-7770-0046

AGNIESZKA MICHAŁOWSKA

AGATA ZŁOTOGÓRSKA-SUWIŃSKA (D) orcid 0000-0002-5075-2900

Wydział Psychologii i Kognitywistyki, Uniwersytet Adama Mickiewicza w Poznaniu Faculty of Psychology and Cognitive Science, Adam Mickiewicz University in Poznań e-mail: putko@amu.edu.pl

\title{
Ekspozycja na fabularną prozę a spontaniczna versus jawna mentalizacja
}

\author{
Exposure to Narrative Fiction and Spontaneous \\ versus Explicit Mentalization
}

\begin{abstract}
The main objective of the study was to check for the existence of the effect of shortterm exposure to fiction in the area of mentalization abilities (Kidd, Castano, 2013), taking into account the spontaneous versus explicit aspect of these abilities. An additional aim was to verify the hypothesis that at the root of this phenomenon lies the process of imaginary simulation. In the first part of the study, participants $(N=103$, aged 18 to 25$)$ were randomly assigned to one of four groups: (1) reading literary fiction, (2) listening to the same story as the first group, and at the same time imagining the events presented in it, (3) reading popular fiction, and (4) not reading any story. In the second part of the study, all participants completed mentalization tests, a test checking familiarity with fiction, and the questionnaire on practices of reading books, magazines and watching television. The study showed no significant differences between the groups in the results of mentalization tests, even under conditions conducive to imaginary simulation. Familiarity with fiction proved to be a positive predictor of spontaneous mentalization, and exposure to television was a negative predictor of explicit mentalization. The findings lead to the conclusion that short-term exposure to fiction does not lead to a significant increase in spontaneous or explicit mentalization. However, both aspects of mentalization are connected with more long-term factors that are expressed in familiarity with fiction and exposure to television.
\end{abstract}

Keywords: theory of mind, reading fiction, imaginary simulation, exposure to television

Słowa kluczowe: teoria umysłu, czytanie utworów beletrystycznych, wyobrażeniowa symulacja, oglądanie telewizji

\section{WPROWADZENIE}

Lektura opowiadania lub powieści, śledzenie tego, co przedstawieni w nich bohaterowie mówią i czynią, wymaga rozumienia ich intencji, przekonań i innych stanów umysłowych. Czyn- ność czytania tego rodzaju utworów wydaje się zatem angażować zdolności mentalizacyjne, polegające na interpretowaniu działań własnych $\mathrm{i}$ innych ludzi jako kierowanych przez ich stany umysłowe (Baron-Cohen, 1995). David Comer Kidd i Emanuele Castano (2013) stwierdzili 
istnienie zjawiska krótkotrwałej ekspozycji na fabularną prozę polegającego na tym, że poprzedzenie pomiaru zdolności mentalizacyjnych już jednorazową lekturą utworu beletrystycznego o walorach literackich (literary fiction) prowadziło u osób dorosłych do uzyskania wyższych wyników w teście mentalizacji w porównaniu z lekturą utworu beletrystycznego z rodzaju literatury popularnej (genre fiction), literatury faktu (nonfiction) lub brakiem jakiejkolwiek lektury. Wyników tych badań nie udało się w pełni zreplikować przez niezależne zespoły badaczy (np. Panero i in., 2016; Samur, Tops, Koole, 2018), co stawia pod znakiem zapytania istnienie tego zjawiska lub świadczy o jego bardzo subtelnym, kruchym charakterze. Niejasny również pozostaje mechanizm, za sprawą którego już jednorazowy kontakt $\mathrm{z}$ fragmentem fabularnej prozy, najlepiej o walorach literackich, jak twierdzą Kidd i Castano (2013), miałby prowadzić do uzyskania wyższych wyników w teście mentalizacji.

Celem obecnego badania była dalsza eksploracja zjawiska ekspozycji na fabularną prozę z uwzględnieniem ważnego, a dotąd pomijanego w tym kontekście aspektu zdolności mentalizacyjnych: spontanicznego versus jawnego (intencjonalnego) ich wykorzystywania. Jeżeli zjawisko krótkotrwałej ekspozycji na fabularną prozę charakteryzuje się małą wielkością efektu, gdy testowane jest za pomocą jawnych miar mentalizacji, jak pokazują dotychczasowe badania, to powstaje pytanie: czy możliwe jest jego zaobserwowanie $\mathrm{z}$ większą wyrazistością przy zastosowaniu bardziej czułych wskaźników zdolności mentalizacyjnych, za jakie uchodzą miary spontanicznej mentalizacji? Kolejne ważne pytanie dotyczy mechanizmu, który leży u podstaw zjawiska ekspozycji na fabularną prozę. Wśród proponowanych wyjaśnień wskazuje się między innymi na proces wyobrażeniowej symulacji (por. np. Oatley, 2016), jak dotąd nie podjęto jednak próby o charakterze eksperymentalnym, aby zweryfikować to przypuszczenie. Uzyskanie odpowiedzi na powyższe pytania pozwoliłoby lepiej poznać naturę zjawiska ekspozycji na fabularną prozę, to jest dokładniej zgłębić mechanizmy wpływu, jaki wywiera kontakt $\mathrm{z}$ utworem beletrystycznym, nawet ten krótkotrwały, na zdolności intelektualne człowieka. W dalszej części artykułu zostanie dokonany krótki przegląd dotychczasowych badań nad tym zjawiskiem, a następnie przedstawione zostaną wyniki badania własnego.

\section{Efekt ekspozycji na fabularną prozę}

Poprawę zdolności mentalizacyjnych bezpośrednio po krótkotrwałej ekspozycji na fabularną prozę stwierdzono w serii pięciu eksperymentów przeprowadzonych przez Kidda i Castano (2013). W eksperymentach tych uczestnicy badania zostali losowo przydzieleni do jednej $\mathrm{z}$ dwóch lub więcej grup różniących się tym, czy bezpośrednio przed pomiarem zdolności mentalizacyjnych ich uczestnicy czytali jakiś tekst, a jeżeli tak, to jakiego był on rodzaju. Badanie pokazało, że osoby czytające opowiadanie o walorach literackich, to jest napisane przez laureata prestiżowej nagrody literackiej, uzyskały istotnie wyższe wyniki w teście $O c z y$ (Reading the Mind in the Eyes Test) (Baron-Cohen i in., 2001) w porównaniu z osobami, które czytały opowiadanie z rodzaju popularnej beletrystyki, tekst niebeletrystyczny lub nie czytały żadnego tekstu. Co ciekawe, istotną różnicę w wynikach między grupami stwierdzono tylko w przypadku testu Oczy, nie odnotowano jej natomiast w teście fałszywego przekonania $\mathrm{w}$ wersji polegającej na ocenie prawdopodobieństwa zachowań głównego bohatera historyjki (Converse i in., 2008) ani też w tak zwanym zadaniu z Yonim (Shamay-Tsoory, Aharon-Peretz, 2007), pozwalającym mierzyć nie tylko poznawczy, ale i afektywny aspekt mentalizacji, czy wreszcie $\mathrm{W}$ teście rozpoznawania emocji DANVA2-AF (Nowicki, 2010). Zdaniem autorów badania brak istotnych różnic między grupami w wynikach tych testów spowodowany jest ich mniejszym stopniem trudności oraz mniejszym zakresem możliwych do uzyskania wyników w porównaniu z testem $O c z y$.

Oprócz efektu krótkotrwałej ekspozycji na fabularną prozę Kidd i Castano (2013) stwierdzili istnienie zjawiska, które można nazwać efektem długotrwałej ekspozycji na fabularną prozę. Polegało ono na tym, że osoby posiadające lepszą znajomość utworów beletrystycznych, 
mierzoną Testem rozpoznawania autorów (Author Recognition Test) (Stanowich, West, 1989; Acheson i in., 2008) uzyskały wyższe wyniki w teście $O c z y$ w trzech spośród czterech eksperymentów, w których test ten został zastosowany. Efekt długotrwałej ekspozycji na literacką prozę nie wchodził w interakcję z efektem krótkotrwałej ekspozycji, a ten ostatni nie był w istotny sposób modyfikowany, jak wykazały dodatkowe analizy, przez takie zmienne uboczne, jak wiek, płeć, nastrój czy stopień „zatopienia się" w lekturze opowiadania. Ta ostatnia zmienna mierzona była za pomocą skali ,przenoszenia się” w świat narracji (transportation scale) Melanii Green i Timothy'ego Brocka (2000).

\section{Badania replikacyjne}

Najpoważniejszą próbę replikacji badań Kidda i Castano (2013) podjęli Maria Panero i współpracownicy (2016). Zastosowali oni w większości ten sam materiał tekstowy co w badaniu oryginalnym, ale znacznie zwiększyli wielkość grup eksperymentalnych, aby podwyższyć szanse wykrycia badanego zjawiska, które według ich analiz cechuje się małą lub umiarkowaną wielkością efektu ( $d$ Cohena w przedziale od .24 do .51). Taka sama była również procedura badania, polegająca $\mathrm{w}$ całości na badaniu internetowym. Badanie nie wykazało, aby wyniki w teście $O c z y$, jedynym teście mentalizacyjnym, jaki został zastosowany, różniły się w zależności od warunku eksperymentalnego, niezależnie od tego, jaki model statystycznej analizy wyników został przyjęty.

Badanie Panero i współpracowników (2016) zostało poddane krytyce przez Kidda i Castano (2017b), według których niepowodzenie w replikacji wyników spowodowane zostało niezachowaniem tych samych zasad analizy wyników co w ich badaniu. W reanalizie danych pochodzących z badania Panero i współpracowników, uwzględniającej odpowiednie poprawki, Kidd i Castano stwierdzili, że grupa czytająca opowiadanie o walorach literackich uzyskała istotnie wyższe wyniki w teście $O c z y$, niż grupa czytająca opowiadanie z rodzaju popularnej beletrystyki. Był to jednakże jedyny wynik zgodny z ich pierwotnym badaniem, ponieważ paradoksalnie okazało się, że ta pierwsza grupa uzyskała wyniki nieróżniące się istotnie od uzyskanych przez grupę czytającą tekst niebeletrystyczny, a ta z kolei wyniki istotnie wyższe niż grupa czytająca tekst $\mathrm{z}$ rodzaju popularnej beletrystyki. Jak zauważają Panero i współpracownicy (2017), odnosząc się do wyników tej reanalizy, chociaż pokazała ona istotną różnicę w wynikach testu mentalizacyjnego na korzyść grupy czytającej literacką prozę w porównaniu z grupą czytającą popularną prozę, to jednak pełny wzór wyników nie odpowiada temu z badania Kidda i Castano (2013). Wyniki sugerują bowiem, że czytanie popularnej prozy wpływa niekorzystnie na zdolności mentalizacyjne zarówno co do czytania prozy literackiej, jak i niebeletrystycznej. Jest to dość paradoksalny wniosek, biorąc pod uwagę, że zastosowane w badaniu niebeletrystyczne teksty nie miały w większości społecznej treści. Efektu krótkotrwałej ekspozycji na fabularną prozę nie udało się również zreplikować w badaniu Dalii Samur i współpracowników (2018).

\section{Inne próby potwierdzenia efektu \\ (krótkotrwałej) ekspozycji na fabularna prozę}

Spośród innych prób potwierdzenia wzrostu zdolności mentalizacyjnych w wyniku mniej lub bardziej krótkotrwałej ekspozycji na fabularną prozę na uwagę zasługują dwie. Są one oparte na innym schemacie badań, niż dotąd prezentowane. Pierwszym jest badanie podłużne Marii Pino i Moniki Mazzy (2016), które odróżnia od pozostałych również to, że jego uczestnicy otrzymali za zadanie przeczytać nie krótkie opowiadanie, lecz całą książkę. Przed i po lekturze tekstu uczestnicy wypełnili (w odstępie 14 dni) obszerny zestaw testów zdolności mentalizacyjnych oraz empatii. Badanie pokazało, że w preteście wszystkie trzy badane grupy - literackiej beletrystyki, niebeletrystyki i science fiction - nie różniły się istotnie wynikami. W postteście natomiast odnotowano istotne różnice na korzyść grupy literackiej beletrystyki w stosunku do dwóch pozostałych w wynikach testów mentalizacyjnych (test fałszywych przekonań I i II rzędu oraz test „Twarze” Barona-Cohena i in., 1997), ale nie empatii. Jak słusznie zauważają Panero i współpracownicy (2016), 
z powodu zastosowania przez Pino i Mazzę w pre- i postteście różnych miar zdolności mentalizacyjnych nie jest jednak całkowicie pewne, czy stwierdzone w postteście różnice między grupami w miarach zdolności mentalizacyjnych są rzeczywiście efektem zastosowanej manipulacji eksperymentalnej.

Drugim badaniem odbiegającym od pozostałych pod względem schematu jest badanie Jessiki Black i Jennifer Barnes (2015), w którym zamiast porównań międzygrupowych zastosowano porównanie wewnątrzgrupowe. Uczestnicy badania zapoznawali się zarówno z opowiadaniem o walorach literackich, jak i z tekstem niebeletrystycznym (warunek kontrolny), za każdym razem po lekturze tekstu wypełniając między innymi test $O c z y$. Badanie pokazało, że wyniki w tym teście były wyższe $\mathrm{w}$ porównaniu z warunkiem kontrolnym, jeżeli przed jego wykonaniem uczestnicy czytali opowiadanie o walorach literackich. Na uwagę w wynikach tego badania zasługuje jednakże to, że efekt ekspozycji na fabularną prozę ujawnił się dopiero wówczas, gdy kontrolowano w analizie statystycznej stopień, w jakim uczestnicy badania przenosili się w wyobraźni w fikcyjny świat opowiadania. Ten wynik nasuwa przypuszczenie, że zjawisko ekspozycji na fabularną prozę może mieć związek z procesem wyobrażeniowej symulacji.

\section{Mechanizm ekspozycji na fabularną prozę}

Wśród proponowanych wyjaśnień pozytywnego wpływu czytania utworów beletrystycznych na zdolności mentalizacyjne najczęściej wymienia się dwa komplementarne względem siebie wyjaśnienia - treściowe i procesualne (Mar, Oatley, 2008; Kidd, Ongis, Castano, 2016; Oatley, 2016). Według wyjaśnienia treściowego kluczowe znaczenie w mechanizmie ekspozycji na fabularną prozę ma sposób przedstawiania postaci w utworach fabularnych, zwłaszcza tych o walorach literackich. Wskazuje się, że postaci w tych utworach są zazwyczaj bardziej złożone niż w tych z rodzaju popularnej beletrystyki, są częściej postaciami wielowymiarowymi niż dwuwymiarowymi - ukazującymi się czytelnikowi z wielu stron (round vs. flat characters,
Forster, 1927). Teksty o walorach literackich również w znacznie większym stopniu niż te z rodzaju popularnej beletrystyki zachęcają czytelnika do przyjęcia aktywnej roli w konstruowaniu fikcyjnego świata, w nadawaniu znaczeń przedstawionym opisom. Odwołując się do wprowadzonego przez Rolanda Barthes'a (1999 [1970]) - rozróżnienia są w większym stopniu tekstami ,do napisania” (writerly) niż „do czytania” (readerly) (Kidd, Castano, 2013; Oatley, 2016).

$\mathrm{Z}$ kolei według wyjaśnienia procesualnego czytanie fabularnej prozy może angażować dwa rodzaje procesów: wnioskowanie oraz ,przenoszenie się" (transportation) w wyobraźni w fikcyjny świat opowiadania. Przedmiotem wnioskowania mogą być przede wszystkim stany wewnętrzne doświadczane przez bohaterów opowiadania, które często, zwłaszcza w utworach o walorach literackich, nie są opisywane wprost, lecz muszą zostać przez czytelnika wywnioskowane na podstawie takich wskazówek, jak wypowiedzi i zachowania bohaterów. Czytanie utworów beletrystycznych może być zatem traktowane jako ćwiczenie w tego rodzaju wnioskowaniu. „Przenoszenie się” z kolei to „proces, w którym wszystkie systemy umysłowe i zdolności koncentrują się na zdarzeniach przedstawionych w narracji” (Green, Brock, 2000, s. 701). Rezultatem tego procesu jest stan emocjonalnego zaangażowania, ,zanurzenia się” w fikcyjnym świecie opowiadania. Uważa się, że ważnym komponentem procesu ,przenoszenia się" jest, oprócz poznawczego i emocjonalnego, komponent wyobrażeniowy, o czym świadczy fakt, że doświadczenie stanu „zanurzenia się” w fikcyjnym świecie opowiadania jest $w$ dużym stopniu związane z żywością wyobrażeń wzbudzonych przez lekturę opowiadania.

Należy zauważyć, że założenie o istotnej roli procesów wyobrażeniowych jest również przyjmowane w koncepcji symulacji jako podstawy zdolności mentalizacyjnych (np. Harris, 2005), stanowiącej obok tak zwanej teorii teorii (np. Perner, 1991) jedno z głównych podejść wyjaśniających naturę zdolności mentalizacyjnych (teorii umysłu). Według koncepcji symulacji, gdy ktoś ma przewidzieć zachowanie innej osoby, to wyobraża sobie, że jest w sytuacji tej 
osoby, a następnie zakłada, że intencje, myśli i inne stany umysłowe, które są wynikiem tej symulacji, odpowiadają temu, czego rzeczywiście doświadcza ta osoba. Pomimo wyraźnego podobieństwa konstruktów ,przenoszenia się” i ,wyobrażeniowej symulacji”, nie sprawdzono dotąd w badaniu eksperymentalnym, w jakim stopniu za efekt krótkotrwałej ekspozycji na fabularną prozę odpowiedzialny jest proces wyobrażeniowej symulacji. Rozstrzygnięcie tego problemu stało się jednym z celów badania własnego.

\section{BADANIE WLASNE}

Głównym celem badania było sprawdzenie, czy krótkotrwała ekspozycja na fabularną prozę u osób w wieku 18-25 lat wywiera bezpośredni wpływ na atrybucję stanów umysłowych (Kidd, Castano, 2013) z uwzględnieniem aspektu spontanicznego versus jawnego wykorzystywania tych zdolności mentalizacyjnych. Aspekt ten nie był dotąd brany pod uwagę w kontekście tego zjawiska. Jego uwzględnienie motywowane było niejednoznacznymi wynikami dotychczasowych badań replikacyjnych (np. Panero i in., 2016; Pino, Mazza, 2016), wskazującymi na małą wielkość efektu ekspozycji na fabularną prozę. Biorąc to pod uwagę, w tym badaniu postanowiono sprawdzić, czy efekt ten będzie można zaobserwować, jeżeli zastosowany zostanie bardziej czuły wskaźnik zdolności mentalizacyjnych, jakim jest mentalizacja spontaniczna. O mentalizacji spontanicznej można mówić wtedy, gdy podmiot dokonuje atrybucji stanów umysłowych bez jawnej do tego zachęty. Mentalizacja jawna natomiast polega na atrybucji stanów umysłowych, która pojawia się w odpowiedzi na zadane wprost pytanie lub polecenie odwołujące się do stanów umysłowych. Różne miary mentalizacji spontanicznej były z powodzeniem wykorzystywane w badaniach dzieci (np. Clements, Perner, 1994) oraz osób dorosłych z zaburzeniami ze spektrum autyzmu (np. Senju i in., 2009). Pozwalają one stwierdzić, czy pewne bodźce wzbudzają u danej osoby reakcję świadczącą o atrybucji stanu mentalnego, nawet jeżeli nie ujawnia ona jawnej mentalizacji.
W obecnym badaniu podjęto próbę sprawdzenia istnienia efektu krótkotrwałej ekspozycji na fabularną prozę z wykorzystaniem miary spontanicznej mentalizacji opracowanej przez Davida Dodell-Federa i współpracowników (2013). Miara ta „odzwierciedla wyrazistość (salience) informacji na temat stanu umysłowego oraz skłonność (propensity) do myślenia o stanach umysłowych" (Dodell-Feder i in., 2013, s. 3). Jak się wydaje, ten pierwszy aspekt (wyrazistość) odnosi się do bieżącego stanu ukierunkowania uwagi jednostki, uwarunkowanego głównie sytuacyjnie (np. w jednych warunkach ta sama informacja może być bardziej wyrazista niż w innych), a ten drugi (skłonność) do względnie trwałej dyspozycji jednostki do zwracania uwagi na stany umysłowe innych ludzi. Można przypuszczać, że wyrazistość informacji o tego rodzaju stanach może zależeć od wielu czynników, na przykład od tego, co było przedmiotem uwagi jednostki wcześniej, lub od tego, jakie inne bodźce docierają do niej obecnie. W naszym badaniu interesowało nas to, czy wcześniejsza ekspozycja na fabularną prozę o walorach literackich przyczyni się do wzrostu wyrazistości stanów umysłowych, co przejawi się w częstszym posługiwaniu się uczestników badania terminami mentalnymi w zadaniu, które bezpośrednio tego nie wymaga ${ }^{1}$.

Drugim celem obecnego badania było zweryfikowanie hipotezy, że u podstaw zjawiska krótkotrwałej ekspozycji na fabularną prozę leży proces wyobrażeniowej symulacji. Zagadnienie to było dotąd przedmiotem jedynie teoretycznych, a nie empirycznych analiz (por. np. Oatley, 2016; Kidd, Castano, 2017b). Przesłanek do uwzględnienia tego procesu dostarczają między innymi wyniki badania Black i Barnes (2015), w którym efekt czytania literackiej prozy ujawnił się dopiero wówczas, gdy statystycznie kontrolowano stopień, w jakim uczestnicy badania ,zanurzali się” w wyobraźni w fikcyjnym świecie opowiadania.

Trzecim wreszcie celem obecnego badania było sprawdzenie, czy poziom zdolności mentalizacyjnych pozostaje w związku nie tylko ze znajomością beletrystyki, jak wykazano w wielu badaniach, ale również z praktykami korzystania 
$\mathrm{z}$ telewizji. $\mathrm{Z}$ jednej strony telewizja - będąc źródłem przede wszystkim obrazowej informacji - może stanowić konkurencję dla lektury książki, nie wymagając jednak od odbiorcy tego samego rodzaju aktywności poznawczej, która związana jest z lekturą utworu beletrystycznego. $\mathrm{Z}$ drugiej strony oglądanie telewizji, w szczególności niektórych filmów fabularnych, może pobudzać zdolności mentalizacyjne, podobnie jak lektura książki. Dotychczasowe badania dotyczące związku między zaangażowaniem w oglądanie telewizji a zdolnościami mentalizacyjnymi, przeprowadzone wśród dzieci w wieku przedszkolnym, nie dały jednoznacznych rezultatów. Jedno badanie pokazało, że poziom zdolności mentalizacyjnych nie wykazuje związku z czasem spędzonym na oglądaniu telewizji (Mar, Tackett, Moore, 2009), drugie natomiast wskazało na negatywny związek (Nathanson $\mathrm{i}$ in., 2013). Nie są nam znane doniesienia dotyczące tego związku u osób dorosłych. $Z$ tego względu interesujące wydaje się sprawdzenie, czy zdolności mentalizacyjne osób dorosłych wiążą się nie tylko z czytaniem fabularnej prozy, ale i z zaangażowaniem w oglądanie telewizji.

Podsumowując: w obecnym badaniu przewidywano, że jeżeli czytanie fabularnej prozy (w szczególności tej o walorach literackich) zwiększa zdolności mentalizacyjne, to nawet jeżeli efekt ten jest niewielki, gdy mierzy się go za pomocą miar mentalizacji jawnej, jak wskazują dotychczasowe badania, to ujawni się on wyraźniej, gdy zostanie zastosowana miara mentalizacji spontanicznej w ujęciu zaproponowanym przez Dodell-Federa i współpracowników (2013). Przewidywano również, że jeżeli u podstaw efektu ekspozycji na fabularną prozę leży mechanizm wyobrażeniowej symulacji, to w warunkach sprzyjających zaangażowaniu wyobraźni w trakcie lektury opowiadania nastąpi silniejszy wzrost wyników w testach mentalizacyjnych niż w warunkach mniej dogodnych do jej zaangażowania lub niewymagających jej zaangażowania. Mówiąc inaczej, oczekiwaliśmy, że jeżeli wcześniejsza lektura opowiadania aktywizuje mechanizm wyobrażeniowej symulacji, to jego działanie będzie ułatwione $\mathrm{w}$ trakcie rozwiązywania testów mentalizacji, co odzwierciedli się w wyższych wynikach.
W odniesieniu do trzeciego pytania badawczego, dotyczącego relacji między zdolnościami mentalizacyjnymi a oglądaniem telewizji, nie postawiono hipotezy, eksplorując ten problem z uwzględnieniem podziału na spontaniczną i jawną mentalizację, co stanowi nowy element w badaniach nad tym zagadnieniem.

\section{METODA}

\section{Uczestnicy}

W badaniu uczestniczyły 103 osoby (w tym 87 kobiet) w wieku od 18 do 25 lat $(M=20.87$; $S D=1.18$ ). Byli to studenci jednej z uczelni wyższych w Poznaniu, którzy w zamian za udział w badaniu mogli otrzymać dodatkowe punkty do zaliczenia jednego z przedmiotów. Rekrutacja do badań odbywała się na zasadzie doboru ochotniczego.

\section{Schemat badania}

Badanie oparto na schemacie eksperymentalno-korelacyjnym. W pierwszej części badania jego uczestnicy zostali losowo przydzieleni do jednej z czterech grup: (1) czytającej opowiadanie o walorach literackich; (2) słuchającej tego samego opowiadania, co grupa pierwsza, lecz jednocześnie wyobrażającej sobie przedstawiane treści; (3) czytającej opowiadanie z rodzaju popularnej literatury i (4) kontrolnej (nieczytającej żadnego tekstu). Wprowadzenie grupy, która zamiast czytać opowiadanie, słuchała go, miało przede wszystkim stworzyć warunki sprzyjające zaangażowaniu wyobraźni² podczas zapoznawania się z opowiadaniem, o co zostali jawnie poproszeni w instrukcji do zadania uczestnicy tej grupy. Słuchowa prezentacja nagrania pozwoliła również wyeliminować różnice między uczestnikami badania pod względem ilości ekspozycji na opowiadanie. Różnice te pojawiają się, gdy uczestnicy sami czytają opowiadanie. W drugiej części badania wszyscy uczestnicy wypełnili testy zdolności mentalizacyjnych, test sprawdzający znajomość beletrystyki oraz kwestionariusz dotyczący praktyk czytania książek, czasopism i oglądania telewizji. 


\section{Narzędzia}

Zastosowano następujące materiały i narzędzia: opowiadania, test $O c z y$, zadanie Krótkie opowiadanie, Test rozpoznawania autorów, Kwestionariusz praktyk czytania i korzystania $z$ mediów oraz ankietę dotyczącą treści wysłuchanego opowiadania.

Opowiadania. Wykorzystano te same dwa opowiadania, które zostały użyte w badaniu Kidda i Castano (2013). Pierwszym opowiadaniem, reprezentującym prozę fabularną o walorach literackich, był Biegacz Dona DeLillo (2013). Drugim, reprezentującym popularną prozę fabularną, był wybrany losowo fragment powieści Grzechy matki Danielle Steel. Oba teksty liczyły około 2 tysięcy wyrazów. Słuchowa wersja opowiadania Biegacz trwała 13 minut i 37 sekund i była czytana głosem kobiety. Lektor nie różnicował głosu, nie stosował emfazy emocjonalnej ani też nie podkreślał najważniejszych fragmentów tekstu, aby nie dostarczać słuchaczom dodatkowych wskazówek na temat tego, czego doświadczali bohaterowie opowiadania.

Test Oczy (Reading the Mind in the Eyes Test) (Baron-Cohen i in., 2001; polska adaptacja: Rynkiewicz, Ptaszek, 2013). Test ten służy do oceny zdolności rozpoznawania złożonych stanów mentalnych. Składa się z jednej fotografii instruktażowej i 36 fotografii testowych przedstawiających twarz ograniczoną do obszaru oczu i ich okolic. Zadaniem uczestnika badania jest wybranie jednej z czterech odpowiedzi, która według niego najlepiej określa to, co osoba przedstawiona na zdjęciu myśli lub czuje. Wynikiem w tym teście jest suma poprawnych odpowiedzi (maks. =36). Rzetelność testu mierzona współczynnikiem Browna-Spearmana wyniosła .74.

Krótkie opowiadanie (Dodell-Feder i in., 2013). Zadanie to służy do pomiaru zdolności mentalizacyjnych u osób dorosłych. Polega ono na zapoznaniu się z opowiadaniem, a następnie udzieleniu odpowiedzi na pytania otwarte dotyczące tego opowiadania. W zadaniu wykorzystano opowiadanie Ernesta Hemingwaya The end of something, którego bohaterami są kobieta i mężczyzna pozostający z sobą w związku, pomiędzy którymi dochodzi do sprzeczki i roz- stania. W opowiadaniu przedstawione zostały wypowiedzi sarkastyczne, mowa ciała oraz próby ukrycia przed drugą osobą swoich emocji $\mathrm{i}$ intencji. Aby zrozumieć społeczne interakcje między bohaterami, konieczne jest rozumienie komunikacji pośredniej i niewerbalnej oraz dokonywanie atrybucji stanów mentalnych zarówno I, jak i II rzędu. Odpowiedzi na pytania mierzące zdolności mentalizacyjne są oceniane w skali od 0 do 2 punktów. Podstawą oceny jest poprawność rozpoznania stanu mentalnego, liczba uwzględnionych perspektyw lub emocji bohaterów opowiadania oraz zrozumienie niewerbalnej i pośredniej komunikacji. Tłumaczenie na język polski opowiadania Hemingwaya pt. Coś się kończy, stanowiące część testu, zaczerpnięto ze zbioru opowiadań Hemingwaya (1963 [1930]) pt. Rzeka dwóch serc i inne opowiadania. Listę pytań do opowiadania oraz klucz do oceny odpowiedzi przygotowano metodą translacji wstecznej. Na podstawie udzielonych przez uczestnika badania odpowiedzi oblicza się trzy wskaźniki: (1) obecność spontanicznej mentalizacji (zakres 0-1 pkt); (2) poziom jawnej mentalizacji (0-16 pkt); (3) rozumienie opowiadania - pytania kontrolne (0-10 pkt). Wskaźnik spontanicznej mentalizacji ma charakter binarny: przyjmuje on wartość 1 , jeżeli w odpowiedzi na polecenie „Napisz w kilku zdaniach, o czym było opowiadanie" uczestnik badania użył przynajmniej jeden raz terminu odnoszącego się do stanów umysłowych. Wskaźnik jawnej mentalizacji jest sumą punktów za odpowiedzi na osiem pytań, z których większość wymaga wyjaśnienia, dlaczego ktoś zachował się w określony sposób lub coś powiedział (np. „Dlaczego Nick powiedział do Marjorie: «Ty wszystko wiesz?»»). Wskaźnik rozumienia opowiadania jest sumą punktów za odpowiedzi na pięć pytań, które dotyczą różnych faktów opisanych w opowiadaniu (np. „Po co Nick i Marjorie mają wiadro z okoniami?") ${ }^{3}$. Aby ocenić rzetelność pomiaru, zastosowano metodę zgodności ocen sędziów kompetentnych. W tym celu około $25 \%$ losowo wybranych arkuszy odpowiedzi zostało ocenionych przez niezależnego sędziego. Współczynniki zgodności ocen dla poszczególnych wskaźników wyniosły: spontaniczna mentalizacja - kappa $=.92$; 
jawna mentalizacja - współczynnik korelacji wewnątrzklasowej $($ ICC $)=.89$; rozumienie opowiadania $-\mathrm{ICC}=.94$.

Test rozpoznawania autorów (Author $\mathrm{Re}$ cognition Test) (Stanovich, West, 1989; Acheson $\mathrm{i}$ in., 2008). Test ten służy do oceny stopnia znajomości beletrystyki, pozwalając uniknąć problemów związanych z podawaniem przez respondentów społecznie aprobowanych odpowiedzi. Ze względu na długi czas, jaki minął od publikacji oryginalnego narzędzia, postanowiono w polskiej wersji tego testu wykorzystać nową pulę nazwisk pisarzy, dostosowaną do bieżącego czasu przeprowadzania badania oraz do warunków polskich. Wersja pilotażowa testu składała się ze 130 nazwisk, z których połowa była nazwiskami pisarzy, w równej liczbie polskich i zagranicznych. Nazwiska pisarzy wybrano na podstawie rankingu bestsellerów Empiku, Amazon oraz strony Lubimyczytać.pl w roku 2017 oraz w kilku poprzednich latach. W instrukcji do testu uczestników badania informowano, że część nazwisk na liście należy do znanych pisarzy, a zadaniem uczestników jest rozpoznanie tych nazwisk. Podobnie jak w wersji oryginalnej testu uczestnicy byli również proszeni o powstrzymanie się od zgadywania i zaznaczanie na liście tylko tych nazwisk, co do których są pewni, że należą do pisarzy. Na podstawie wyników badania pilotażowego z listy usunięto nazwiska pisarzy rozpoznanych przez największą liczbę badanych oraz nazwiska osób niebędących pisarzami, które były najrzadziej mylone z nazwiskami pisarzy. W ostatecznej wersji testu znalazło się 100 nazwisk, w tym 50 nazwisk znanych pisarzy i 50 nazwisk osób, które nie były pisarzami. W grupie pisarzy połowę stanowili polscy autorzy. Wskaźnikiem stopnia znajomości beletrystyki była różnica między liczbą prawidłowo rozpoznanych nazwisk pisarzy (maks. 50) a liczbą nieprawidłowych rozpoznań. Rzetelność testu mierzona współczynnikiem $\alpha$ Cronbacha wyniosła .84 .

Kwestionariusz praktyk czytania $i$ korzystania $z$ mediów (Reading and Media Habits Questionnaire) (Stanovich, West, 1989). Kwestionariusz składał się z dwóch skal: Czytania i Oglądania telewizji. Pierwszą skalę tworzyło sześć pytań zamkniętych i trzy otwarte; drugą skalę - dwa pytania zamknięte i dwa otwarte. Pytania ze skali Czytania mierzyły zaangażowanie w czytanie książek i czasopism. Dotyczyły one tego, jak często respondent czyta dla przyjemności, ile książek, nie licząc podręczników, czyta w ciągu roku, z ilu bibliotek korzysta itp. Pytania ze skali Oglądania telewizji mierzyły bieżące i przeszłe (w okresie uczęszczania do szkoły) zaangażowanie w oglądanie telewizji. W pytaniach otwartych w obu skalach respondent proszony był o podanie informacji, które pozwalały potwierdzić szczerość odpowiedzi udzielonych na pytania zamknięte (np. ulubieni autorzy książek, ulubione programy telewizyjne). W skali Czytania można było uzyskać maksymalnie 21 pkt, w skali Ogladania telewizji - 8 pkt. Polska wersja językowa kwestionariusza przygotowana została metoda translacji wstecznej. Rzetelność ( $\alpha$ Cronbacha) dla odpowiedzi na pytania zamknięte wyniosła .71, a zgodność ocen sędziów kompetentnych dla pytań otwartych ICC -.89 .

Ankieta na temat wystuchanego opowiadania. Uczestnicy grupy słuchającej opowiadania udzielili odpowiedzi na pięć pytań kontrolnych ${ }^{4}$ dotyczących treści opowiadania. Streszczenie opowiadania oraz pytania do niego przedstawiono w załączniku 1. Odpowiedzi na pytania kontrolne nie wymagały wnioskowania o stanach mentalnych, lecz jedynie przywołania z pamięci informacji bezpośrednio zawartej w opowiadaniu ${ }^{5}$. Za każdą prawidłową odpowiedź przyznawano $1 \mathrm{pkt}$.

\section{Procedura}

Uczestników rekrutowano za pomocą ogłoszeń informujących o poszukiwaniu osób chętnych do wzięcia udziału w badaniach dotyczących własności psychometrycznych polskich adaptacji testów psychologicznych. Zastosowano losowy dobór osób do jednej z czterech grup: czytającej opowiadanie o walorach literackich, słuchającej opowiadania o walorach literackich, czytającej opowiadanie z rodzaju literatury popularnej oraz kontrolnej - nieczytającej żadnego tekstu. Badania prowadzono w grupach liczących od 2 do 5 osób, w cichym pomieszczeniu, w warunkach zapewniających każdemu uczestnikowi możliwość skupienia się na 
zadaniach $^{6}$. Przed przystąpieniem do badania wszyscy uczestnicy zapoznali się z jego opisem i wyrazili pisemną zgodę na udział w nim. Po podaniu danych demograficznych uczestnicy grupy kontrolnej przystępowali do udzielania odpowiedzi w testach mentalizacji, natomiast uczestnicy pozostałych grup przechodzili do zapoznania się z opowiadaniem. W grupach czytających opowiadanie informowano w instrukcji, że pierwszym zadaniem będzie przeczytanie opowiadania, i proszono, aby uczestnicy zrobili to uważnie. Czas zapoznawania się z opowiadaniem przez osoby czytające wynosił od 11 do 15 minut. W grupie słuchającej opowiadania treść instrukcji brzmiała: ,Za chwilę wysłuchasz krótkiego opowiadania. Słuchając go uważnie, postaraj się postawić na miejscu głównego bohatera tego opowiadania. Wyobraź sobie to, co on widzi, co myśli i co czuje". Osoby, które wysłuchały opowiadania, przed przystąpieniem do testów mentalizacji wypełniały krótką ankietę na temat treści opowiadania. Kolejność wypełnianych testów była taka sama dla wszystkich uczestników i przedstawiała się następująco: test Oczy, zadanie Krótkie opowiadanie, Test rozpoznawania autorów oraz Kwestionariusz praktyk czytania i korzystania z mediów. Na potrzeby innego badania uczestnicy wypełniali jeszcze jeden lub dwa inne kwestionariusze, których wyniki nie są w obecnym artykule analizowane. Po wypełnieniu wszystkich testów były one oddawane w zaklejonej kopercie w sposób uniemożliwiający identyfikację uczestnika badania. Na koniec informowano uczestników o dodatkowym celu badania, jakim było sprawdzenie efektu ekspozycji na fabularną prozę.

\section{WYNIKI}

\section{Analiza wstępna}

Przed przystąpieniem do właściwych analiz zebrane dane sprawdzono pod względem obserwacji odstających ( \pm 3 SD od średniej) oraz braków danych. Z analizy usunięto wyniki pięciu osób: jedna osoba nie wypełniła Testu rozpoznawania autorów; jedna osoba nie udzieliła ani jednej poprawnej odpowiedzi na pytania kontrolne sprawdzające rozumienie treści opowiadania w zadaniu Krótkie opowiadanie; jedna osoba uzyskała wyniki odstające w teście Oczy i dwie osoby uzyskały wyniki odstające w Teście rozpoznawania autorów. Po eliminacji próba liczyła 98 osób. W tabeli 1 przedstawiono rozkład płci, wieku oraz wyników testów mentalizacyjnych w badanych grupach: czytania literackiej prozy, słuchania literackiej prozy, czytania popularnej prozy oraz kontrolnej. Grupy nie różniły się istotnie pod względem liczby kobiet i mężczyzn $\left(\chi^{2}=1.11, \mathrm{df}=3, p=.776\right)$ oraz wieku, $F(3,94)=.79, p=.500$.

W grupie, która słuchała opowiadania (Ls), średnia liczba poprawnych odpowiedzi na pięć pytań kontrolnych w ankiecie dotyczącej treści wysłuchanego opowiadania wyniosła 4.16 na 5 możliwych (mediana $=4$; zakres $2-5$ ). Nie zachodził istotny związek między poprawnością odpowiedzi na te pytania a miarami mentalizacji (dla mentalizacji spontanicznej: rho $=.11$; dla mentalizacji jawnej: rho $=.08$; dla testu $O c z y$ : rho $=-.10$; wszystkie $p>.61$ ), co wskazuje, że pytania te sprawdzały inny rodzaj zdolności niż testy mentalizacji. Z kolei średnia liczba

Tabela 1. Dane demograficzne badanych grup oraz wyniki testów mentalizacyjnych

\begin{tabular}{|c|c|c|c|c|c|c|}
\hline \multirow{2}{*}{ Grupa } & \multirow{2}{*}{$\mathbf{N}$} & \multirow{2}{*}{ Kobiety } & Wiek & Test Oczy & KO jawna & KO spont. \\
\cline { 4 - 7 } & & M SD & M SD & M SD & [\%] \\
\hline Lc & 22 & 18 & 21.181 .44 & $26.363,08$ & $9.271,75$ & 55 \\
\hline Ls & 25 & 22 & 20.841 .25 & $26.843,58$ & $9.842,53$ & 64 \\
\hline Pc & 26 & 20 & 20.77 .99 & $26.193,27$ & $9.542,83$ & 54 \\
\hline Kn & 25 & 20 & 20.681 .03 & $25.923,44$ & $9.242,09$ & 48 \\
\hline
\end{tabular}

Objaśnienia: Lc - grupa czytająca literacką prozę, Ls - grupa słuchająca literackiej prozy, Pc - grupa czytająca popularną prozę, $\mathrm{Kn}$ - grupa kontrolna, $\mathrm{KO}$ - zadanie Krótkie opowiadanie, KO jawna - zadanie, jawna mentalizacja, KO spont. - zadanie, spontaniczna mentalizacja 
punktów uzyskanych za odpowiedzi na pytania kontrolne w zadaniu Krótkie opowiadanie wyniosła 9.08 na 10 możliwych (mediana = 9; zakres 5-10). Badane grupy nie różniły się istotnie pod względem liczby tych punktów, $F(3,94)$ $=1.38, p=.254, \eta_{p}{ }^{2}=.042$. Liczba terminów mentalnych, które pojawiły się w odpowiedzi na pytanie mierzące mentalizację spontaniczną w zadaniu Krótkie opowiadanie wyniosła od 0 do 7, mediana 1, co uzasadnia, podobnie jak w badaniu Dodell-Federa i współpracowników (2013), posłużenie się binarnym wskaźnikiem spontanicznej mentalizacji. Liczba błędnych odpowiedzi w Teście rozpoznawania autorów mieściła się $\mathrm{w}$ przedziale od 0 do 4 , mediana 0 ; w przypadku żadnej osoby liczba ta nie była większa niż liczba poprawnych odpowiedzi. Podobnie jak w badaniu Kidda i Castano (2013) oraz w badaniach replikacyjnych (np. Panero i in., 2016) wartości wyników w Teście rozpoznawania autorów poddano transformacji, wyznaczając ich pierwiastek kwadratowy. Po transformacji skośność rozkładu tych wyników wyniosła -.224; w tabeli 2 prezentowane są wartości nieprzekształcone tej zmiennej.

Dwa pytania w Kwestionariuszu praktyk czytania i korzystania z mediów dotyczyły ilości czasu spędzanego na oglądaniu telewizji w okresie uczęszczania do szkoły oraz obecnie. Największa grupa uczestników badania (53\%) odpowiedziała, że kiedy chodziła do szkoły, oglądała telewizję średnio przez 1 do 3 godzin dziennie, $37 \%$ robiło to mniej niż przez jedną godzinę dziennie, $6 \%$ przez 3 do 6 godzin dziennie i 4\% deklarowało, że prawie nigdy nie oglądało telewizji. Jeżeli chodzi o ilość czasu obecnie spędzanego przed telewizorem, to nieznacznie więcej niż połowa uczestników (54\%) stwierdziła, że jest to mniej niż jedna godzina dziennie, $28 \%$ odpowiedziało, że prawie nigdy nie ogląda telewizji, 14\% ogląda telewizję przez 1 do 3 godzin dziennie i 4\% przez 3 do 6 godzin dziennie. Żaden z uczestników nie odpowiedział, że w przeszłości lub obecnie ogląda telewizję przez więcej niż 6 godzin dziennie. Na podstawie tych wyników można stwierdzić, że uczestnicy badania byli grupą zróżnicowaną pod względem ilości czasu spędzanego przed telewizorem i chociaż nieco więcej niż połowa uczestników zadeklarowała, że obecnie ogląda telewizję średnio przez mniej niż jedną godzinę dziennie, to w odniesieniu do okresu uczęszczania do szkoły najczęściej wybieraną kategorią odpowiedzi była ta mówiąca o 1 do 3 godzin dziennie.

Chociaż poszczególne grupy nie różniły się między sobą proporcją kobiet do mężczyzn, sprawdzono w pełnej próbie, czy występują istotne różnice między płciami pod względem badanych zmiennych. Jedyna różnica, która osiągnęła istotność statystyczną, wystąpiła w przypadku spontanicznej mentalizacji: więcej kobiet $(60 \%)$ niż mężczyzn (33\%) ujawniło ten rodzaj mentalizacji, $\chi^{2}=4.22$, df $=1, p=$ .040. Z tego względu w analizach dotyczących spontanicznej mentalizacji jako zmiennej zależnej kontrolowany będzie statystycznie wpływ płci.

Tabela 2. Statystyki opisowe wyników w poszczególnych zadaniach dla pełnej próby $(\mathrm{N}=98)$

\begin{tabular}{|l|c|c|c|c|c|c|}
\hline \multicolumn{1}{|c|}{ Zadanie } & M & SD & Min. & Maks. & Skośność & SE \\
\hline Test Oczy & 26.33 & 3.32 & 19 & 32 & -.219 & .244 \\
\hline KO - jawna mentalizacja & 9.48 & 2.33 & 3 & 15 & -.167 & .244 \\
\hline KO - spont. mentalizacja [\%] & 55 & & & & & \\
\hline TRA & 16.14 & 7.99 & 1 & 39 & .493 & .244 \\
\hline KPCiKM - czytanie & 8.46 & 2.70 & 2 & 16 & .314 & .244 \\
\hline KPCiKM - oglądanie TV & 2.56 & 1.12 & 0 & 6 & .447 & .244 \\
\hline
\end{tabular}

Objaśnienia: KO - zadanie Krótkie opowiadanie, TRA - Test rozpoznawania autorów, KPCiKM - Kwestionariusz praktyk czytania i korzystania $z$ mediów 


\section{Analiza główna}

Aby sprawdzić, czy zachodzą istotne różnice między badanymi grupami w wynikach testu $O c z y$ oraz we wskaźniku jawnej mentalizacji w zadaniu Krótkie opowiadanie, podobnie jak w badaniu Kidda i Castano (2013), zastosowano analizę kowariancji (ANCOVA), z czynnikiem grupa oraz znajomościa beletrystyki (wynikami w Teście rozpoznawania autorów) jako współzmienną. Analiza dla testu $O c z y$ wykazała brak istotnego efektu grupy, $F(3,90)=1.57, p=.202$, $\eta_{p}^{2}=.05$, znajomości beletrystyki, $F(1,90)=$ $1.17, p=.283, \eta_{p}^{2}=.01$, oraz efektu interakcji obu zmiennych, $F(3,90)=1.42, p=.244, \eta_{p}{ }^{2}=$ .05 . Podobne rezultaty przyniosła ANCOVA dla wskaźnika jawnej mentalizacji - grupa: $F(3,90)$ $=.39, p=.760, \eta_{p}^{2}=.01$, znajomość beletrystyki: $F(1,90)=1.30, p=.257, \eta_{p}^{2}=.01$, interakcja obu zmiennych: $F(3,90)=.38, p=., 768, \eta_{p}{ }^{2}$ $=.01$. Obraz wyników analizy kowariancji dla mentalizacji jawnej nie zmienił się istotnie, gdy jako współzmienna została dodatkowo uwzględniona liczba poprawnych odpowiedzi na pytania kontrolne w zadaniu Krótkie opowiadanie, która nie wiązała się istotnie ze zmienną zależną: $F(1,90)=1.57, p=.214, \eta_{p}^{2}=.02$.

W celu sprawdzenia wpływu grupy oraz stopnia znajomości beletrystyki na poziom spontanicznej mentalizacji, której wskaźnik miał charakter binarny, zastosowano logistyczną analizę regresji. Ponieważ zmienna niezależna grupa przyjmowała więcej niż dwa poziomy, stworzono zmienne instrumentalne metodą kodowania zero-jedynkowego (dummy variable). Do modelu regresji wprowadzono w pierwszym bloku zmienne instrumentalne reprezentujące zmienną grupa oraz zmienną znajomość beletrystyki, a następnie w bloku drugim wprowadzono wyrażenie reprezentujące interakcję tych zmiennych. Analiza wykazała, że istotnym pozytywnym predyktorem spontanicznej mentalizacji była znajomość beletrystyki, $B=.592$, Wald $=6.85, \mathrm{df}=1, p=.009, \operatorname{Exp}(B)=1.81$; natomiast ani zmienna grupa, Wald $=2.13$, $\mathrm{df}=3, p=.547$, ani wprowadzony $\mathrm{w}$ drugim bloku składnik interakcyjny, Wald $=2.86, \mathrm{df}=3$, $p=.414$, nie były istotnymi predyktorami. Znajomość beletrystyki pozostała istotnym pre- dyktorem, gdy jako współzmienna w analizie regresji została uwzględniona również liczba poprawnych odpowiedzi na pytania kontrolne w zadaniu Krótkie opowiadanie, która okazała się istotnym predyktorem: $B=.424$, Wald $=$ $4.31, \mathrm{df}=1, p=.038, \operatorname{Exp}(B)=1.53$. Ponieważ mentalizacja spontaniczna była jedyną zmienną, dla której, jak pokazała analiza wstępna, różnice międzypłciowe osiągnęły istotność statystyczną, sprawdzono, czy zmieni się obraz wyników analizy regresji, gdy zmienna ta zostanie włączona do modelu. Okazało się, że płeć umieszczona $\mathrm{w}$ modelu razem $\mathrm{z}$ innymi zmiennymi nie była istotnym predyktorem $(p=.164)$ mentalizacji spontanicznej, natomiast znajomość beletrystyki pozostała jej istotnym predyktorem $(p=.015)$.

Ponieważ dotychczasowe analizy pokazały, że nie ma istotnych różnic między badanymi grupami w wynikach testów mentalizacyjnych, w następnej serii analiz połączono wyniki grupy czytającej i słuchającej opowiadania o walorach literackich oraz porównano je z wynikami również połączonych dwóch pozostałych grup: czytającej opowiadanie z rodzaju literatury popularnej i nieczytającej żadnego tekstu. Należy przypomnieć, że między tymi ostatnimi grupami w badaniach Kidda i Castano (2013), podobnie jak w obecnym, nie było istotnych różnic w wynikach testu $O c z y$, w związku z czym grupy te mogą stanowić punkt odniesienia. Pierwsza powstała w ten sposób grupa, ,literacka”, liczyła 47 osób, druga, ,kontrolna” 51. Średni wynik w teście $O c z y$ w pierwszej grupie wyniósł 26.62 , $S D=3.33$; w grupie drugiej 26.06, $S D=3.32$. Analizy kowariancji ANCOVA, z czynnikiem grupa i współzmienną znajomość beletrystyki, dla wyników w teście Oczy oraz dla wskaźnika jawnej mentalizacji nie wykazały istotnych efektów głównych ani też interakcji obu zmiennych (wszystkie $p \geq .100$ ).

$\mathrm{Z}$ kolei dla mentalizacji spontanicznej analiza regresji logistycznej wykazała istotny efekt główny znajomości beletrystyki, $B=.532$, Wald $=6.06, \mathrm{df}=1, p=.014, \operatorname{Exp}(B)=1.70, \mathrm{i}$ brak istotnego efektu grupy, Wald $=.55, \mathrm{df}=1$, $p=.460$, oraz interakcji grupy i znajomości beletrystyki, Wald $=.15, \mathrm{df}=1, p=.702$. Liczba poprawnych odpowiedzi na pytania kontrolne w zadaniu Krótkie opowiadanie, wprowadzona 
Tabela 3. Współczynniki korelacji ( $r$ Pearsona) między miarami mentalizacji, TRA i KPCiKM

\begin{tabular}{|l|c|c|c|c|c|}
\hline & $\mathbf{1}$ & $\mathbf{2}$ & $\mathbf{3}$ & $\mathbf{4}$ & $\mathbf{5}$ \\
\hline Test $O c z y$ & & & & & \\
\hline KO spont. & $.248^{*}$ & & & & \\
\hline KO jawna & .105 & $.353^{* *}$ & & & \\
\hline TRA & .079 & $.210^{*}$ & .091 & & \\
\hline KPCiKM - czytanie & -.002 & -.007 & $.169^{*}$ & $.294^{* *}$ & \\
\hline KPCiKM - oglądanie TV & -.023 & -.048 & $-.221^{*}$ & -.056 & -.035 \\
\hline
\end{tabular}

Objaśnienia: KO - zadanie Krótkie opowiadanie, TRA - Test rozpoznawania autorów, KPCiKM - Kwestionariusz praktyk czytania i korzystania $z$ mediów

$\# \mathrm{p}<.1 ; * \mathrm{p}<.05 ; * * \mathrm{p}<.01$ (dwustronnie)

do równania regresji jako dodatkowa współzmienna, okazała się istotnym predyktorem spontanicznej mentalizacji, $B=.420, p=.036$, natomiast płeć nie $(p=.168)$, nie zmieniło to jednak w sposób istotny wcześniejszych wyników - efekt główny znajomości beletrystyki pozostał istotny $(p=.023)$.

\section{Analiza korelacji}

W analizie korelacji dla pełnej próby sprawdzono związki między miarami mentalizacji a wynikami w Teście rozpoznawania autorów oraz Kwestionariuszu praktyk czytania i korzystania z mediów.

Analiza pokazała, że wśród miar zdolności mentalizacyjnych zachodzi dodatnia korelacja między wynikiem w teście $O c z y$ a spontaniczną mentalizacją oraz między tą ostatnią a jawną mentalizacją (por. tabela 3). Jeżeli chodzi o wyniki w Teście rozpoznawania autorów, to zgodnie z wynikami analiz kowariancji były one istotnie powiązane ze wskaźnikiem spontanicznej mentalizacji. Natomiast wyniki w skali Czytanie KPCiKM korelowały dodatnio z wynikami w Teście rozpoznawania autorów, a wyniki w skali Oglądanie telewizji korelowały ujemnie $\mathrm{z}$ jawną mentalizacją.

\section{DYSKUSJA}

Głównym celem obecnego badania było sprawdzenie istnienia efektu krótkotrwałej ekspozycji na fabularną prozę (Kidd, Castano, 2013) przy wykorzystaniu miar mentalizacji spontanicznej i jawnej. Oprócz zadania Krótkie opowiadanie zastosowano w obecnym badaniu test $O c z y$, podobnie jak w badaniu oryginalnym. Biorąc pod uwage raportowane $\mathrm{w}$ literaturze przedmiotu dane, wskazujące na niezbyt dużą wielkość efektu ekspozycji na fabularną prozę, oczekiwaliśmy, że jeżeli to zjawisko rzeczywiście zachodzi, to ujawni się ono wyraźniej na poziomie spontanicznej mentalizacji, uchodzącej za bardziej wrażliwą miarę zdolności mentalizacyjnych niż miary mentalizacji jawnej. Uzyskane wyniki nie potwierdziły jednak tych oczekiwań. Badanie pokazało, że nie było istotnej różnicy w wynikach testów mentalizacyjnych między grupami poddanymi ekspozycji na literacką prozę a grupą czytającą opowiadanie z rodzaju popularnej beletrystyki lub grupą nieczytającą żadnego tekstu. Było tak zarówno wtedy, gdy wyniki testów mentalizacyjnych grupy czytającej i słuchającej opowiadania o walorach literackich analizowano osobno, jak i wówczas, gdy połączono je i analizowano razem. Brak efektu krótkotrwałej ekspozycji na fabularną prozę jest zgodny $\mathrm{z}$ wynikami wcześniejszych badań replikacyjnych opartych na większych próbach niż nasza (Panero i in., 2016; Samur i in., 2018), w których również nie stwierdzono tego efektu. Wynik ten stawia pod znakiem zapytania uniwersalność tego zjawiska i wymaga odpowiedzi na dalsze pytania dotyczące warunków, w których ewentualnie się ono ujawnia (Panero i in., 2016).

Należy zauważyć, że podobnie jak we wcześniejszych badaniach (np. Kidd, Castano, 2013; Panero i in., 2016) nie stwierdzono również $\mathrm{w}$ obecnym istotnego interakcyjnego wpływu 
warunków eksperymentalnych i znajomości beletrystyki. To pozwala wykluczyć przypuszczenie, że efekt krótkotrwałej ekspozycji na fabularną prozę ujawnia się być może tylko u osób o małej znajomości beletrystyki, a więc mało czytających, dla których nawet krótkotrwała ekspozycja na fabularną prozę mogłaby stanowić wystarczająco silny bodziec do większego zaangażowania zdolności mentalizacyjnych, niż czynią to na co dzień.

Z kolei fakt, iż poziom spontanicznej mentalizacji nie był istotnie wyższy w grupach, w których eksponowano literacką beletrystykę, w porównaniu $\mathrm{z}$ pozostałymi grupami, natomiast wystąpił istotny związek między spontaniczną mentalizacją a znajomością beletrystyki (Test rozpoznawania autorów), pozwala wykluczyć wyjaśnienie, sugerowane przez niektórych badaczy (np. Oatley, 2016), że efekt krótkotrwałej ekspozycji na fabularną prozę, stwierdzony w badaniu Kidda i Castano (2013), jest być może skutkiem procesu torowania (priming). Proces ten mógłby wystąpić w wyniku aktywacji pojęć odnoszących się do stanów mentalnych, spowodowanej lekturą opowiadania angażującą zdolności mentalizacyjne. Fakt, iż w badanych grupach poziom spontanicznej mentalizacji nie różnił się istotnie, natomiast wiązał się pozytywnie ze znajomością beletrystyki, może świadczyć o tym, że spontaniczna mentalizacja kształtuje się między innymi pod wpływem długotrwałej ekspozycji na fabularną prozę. Ze względu jednak na korelacyjny charakter tych danych nie można wykluczyć przeciwnej interpretacji, że to większe zdolności mentalizacyjne i związana z nimi większa skłonność do spontanicznej atrybucji stanów mentalnych sprawiają, że ktoś jest bardziej zainteresowany beletrystyką i lepiej ją zna.

Drugim celem obecnego badania było sprawdzenie hipotezy, że u podstaw zjawiska krótkotrwałej ekspozycji na fabularną prozę leży proces wyobrażeniowej symulacji. W tym celu jedna $\mathrm{z}$ grup zamiast czytać opowiadanie słuchała go, co miało stworzyć warunki sprzyjające wyobrażaniu sobie tego, co myślą i czują bohaterowie opowiadania, o co uczestnicy tej grupy zostali poproszeni $\mathrm{w}$ instrukcji. Zastosowana manipulacja eksperymentalna, polegająca na stworzeniu warunków sprzyjających zaangażowaniu wyobraźni w trakcie lektury tekstu, jest pierwszą znaną nam próbą sprawdzenia roli tego czynnika w mechanizmie efektu krótkotrwałej ekspozycji na fabularną prozę. Badanie pokazało, że grupa wyobrażająca sobie uzyskała wprawdzie nieco wyższe wyniki przede wszystkim w zakresie mentalizacji spontanicznej, w porównaniu z grupą jedynie czytającą to samo opowiadanie bez wyobrażania sobie, jednak różnica nie osiągnęła istotności statystycznej. Wynik ten przemawia przeciwko hipotezie wyobrażeniowej symulacji jako procesu leżącego u podstaw zjawiska krótkotrwałej ekspozycji na fabularną prozę. Wniosek ten należy jednak traktować ostrożnie, ponieważ w obecnym badaniu nie kontrolowano tego, w jakim stopniu skuteczna była założona manipulacja, na przykład jak bardzo wyraziste były wyobrażenia uczestników tej grupy. Nie można też wykluczyć, że mechanizm wyobrażeniowej symulacji działa, ale nie jest najważniejszym czynnikiem odpowiedzialnym za zjawisko krótkotrwałej ekspozycji na fabularną prozę, stąd też nie udało się zaobserwować wystarczająco silnych efektów jego działania przy tej wielkości próby, jak w obecnym badaniu. Do kwestii tych wrócimy w dalszej części dyskusji dotyczącej ograniczeń obecnego badania i kierunków dalszych badań.

Trzecim wreszcie celem badania było sprawdzenie związków między zdolnościami mentalizacyjnymi a długotrwałą ekspozycją nie tylko na beletrystykę, ale również na telewizję. Do kontroli tego ostatniego czynnika skłonił nas fakt wzrastającej we współczesnym świecie roli mediów opartych na obrazie i związanych z tym zmian w aktywności poznawczej człowieka. Dodatkową przesłanką uzasadniającą uwzględnienie tego czynnika są niejednoznaczne wyniki badań nad związkiem między zdolnościami mentalizacyjnymi a ekspozycją na telewizję u dzieci (Mar i in., 2010; Nathanson i in., 2013) oraz brak, jak dotąd, tego typu analiz u osób dorosłych. Nasze badanie pokazało istnienie negatywnego związku między ekspozycją na telewizję a jawną mentalizacją. Nie było jednocześnie istotnych związków ze spontaniczną mentalizacją oraz $\mathrm{z}$ rozpoznawaniem stanów 
umysłowych na podstawie informacji percepcyjnej (test $O c z y$ ). Ten wzór wyników może wskazywać, że niekorzystny wpływ spędzania dłuższego czasu przed telewizorem ogranicza się do zdolności wnioskowania o stanach mentalnych innych ludzi, mierzonej przez pytania otwarte w zadaniu Krótkie opowiadanie (kognitywny komponent teorii umysłu według koncepcji Tager-Flusberg i Sullivan, 2000). Nie dotyczy on natomiast zdolności związanych $z$ rozpoznawaniem stanów mentalnych na podstawie wskazówek mimicznych (percepcyjny komponent teorii umysłu, mierzony przez test $O c z y)$. Niekorzystny wpływ oglądania telewizji na wnioskowanie o stanach mentalnych może być związany z tym, że przekaz oparty głównie na obrazie (audiowizualny) narzuca W znacznym stopniu sposób widzenia zdarzeń i postaci, ograniczając możliwość samodzielnego konstruowania wyobrażeń przez odbiorcę przekazu, a tym samym ograniczając możliwość uczestniczenia przez niego w tworzeniu fikcyjnego świata opowiadania, do czego zachęca jego lektura w tekstowej formie (Green, Brock, 2002). Nie można jednak wykluczyć, że niekorzystny wpływ oglądania telewizji na zdolności jawnego wnioskowania o stanach mentalnych innych ludzi, jaki sugerują rezultaty naszego badania, wynika nie tyle z obrazowego sposobu przekazywania treści, ile z charakteru oglądanych treści i stopnia, w jakim zachęcają odbiorcę do refleksji nad stanami mentalnymi. Celem naszego badania nie było rozstrzygnięcie tego, która $\mathrm{z}$ tych interpretacji jest słuszna, niemniej zagadnienie to może stanowić jeden z kierunków badań przyszłych. Należy również zauważyć, iż ze względu na korelacyjny charakter tej części badania, która dotyczyła relacji między zdolnościami mentalizacji a ekspozycją na telewizję, nie jest wykluczone, że kierunek rozpatrywanej tu zależności jest odwrotny, to znaczy posiadanie niższych zdolności mentalizacji (zwłaszcza w zakresie wnioskowania o stanach mentalnych) zachęca do spędzania większej ilości czasu przed telewizorem zamiast na przykład na lekturze książek albo też skłania do oglądania takich treści w telewizji, które nie wymagają angażowania tego rodzaju zdolności.

\section{Ograniczenia badania i kierunki dalszych}

W naszym badaniu nie kontrolowaliśmy stopnia wyrazistości wyobrażeń tworzonych przez uczestników grupy słuchającej opowiadania. Nie wiadomo więc, do jakiego stopnia skuteczna była manipulacja eksperymentalna. Co więcej, nie wiemy również, czy w grupach, które czytały opowiadanie, ale nie były zachęcane do wyobrażania sobie opisywanych scen, ich uczestnicy nie tworzyli spontanicznie wyobrażeń, i jeżeli tak, to jak bardzo były one wyraziste. Nie kontrolowaliśmy również stopnia, w jakim uczestnicy badania ,przenosili się” w wyobraźni w fikcyjny świat opowiadania $\mathrm{w}$ trakcie zaznajamiania się $\mathrm{z}$ nim. Brak pomiaru tych zmiennych podyktowany był przyjętym przez nas założeniem, że przerwa między lekturą tekstu a udzielaniem odpowiedzi w testach mentalizacyjnych powinna być ograniczona do minimum. Zważywszy na raportowane w literaturze dane, wskazujące na kruchość badanego zjawiska, chcieliśmy uniknąć wydłużenia tego czasu, co byłoby nieuniknione w przypadku zastosowania skal kontrolujących wymienione wyżej zmienne. Należy jednocześnie zauważyć, że w grupie słuchającej opowiadania uczestnicy wypełniali ankietę sprawdzającą, jak uważnie śledzili opowiadanie, co już wydłużało czas między zakończeniem ekspozycji na fabularną prozę a pomiarem zdolności mentalizacyjnych. W związku z tym w przyszłych badaniach należy rozważyć rezygnację z niektórych użytych w obecnym badaniu narzędzi i zastosowanie w ich miejsce miar do oceny wyrazistości wyobrażeń oraz stopnia ,zatopienia się” w lekturze opowiadania.

Następnym ograniczeniem badania był fakt, że grupa, która miała za zadanie wyobrażać sobie wydarzenia opisane w opowiadaniu, zapoznawała się z opowiadaniem w inny sposób niż dwie pozostałe grupy - słuchając go, zamiast czytać. Jak już zostało wspomniane, rozwiązanie takie zostało zastosowane po to, aby stworzyć uczestnikom tej grupy dogodne warunki do tworzenia wyobrażeń (por. również uzasadnienie dla tego rozwiązania - przypis 2). I chociaż można przypuszczać, że do braku istotnych różnic w wynikach testów mentalizacyjnych między 
grupą słuchającą a czytającą opowiadanie nie mogły się raczej przyczynić trudności w śledzeniu opowiadania przez tę pierwszą grupę (przynajmniej nie wykazała takich trudności ankieta sprawdzająca zapamiętanie treści opowiadania), to jednak nie można wykluczyć, że na uzyskane wyniki mogły wpłynąć inne czynniki związane $\mathrm{z}$ różnicami w procedurze badania (np. wspomniany już sam fakt wypełniania przez jedną z grup ankiety lub sposób prezentacji opowiadania). Wprawdzie przeprowadzone przez nas dodatkowe analizy nie wskazują, aby użycie ankiety sprawdzającej zapamiętanie treści opowiadania miało wpływ na wyniki w testach mentalizacji w grupie słuchającej opowiadania, ale zastosowanie takiej samej procedury badania we wszystkich grupach pozwoliłoby traktować uzyskane wyniki z większym zaufaniem. Kolejnym ograniczeniem badania była niewątpliwie przewaga liczby kobiet nad mężczyznami w badanej próbie, co nie pozwoliło, podobnie jak w badaniu Marii Chiary Pino i Moniki Mazzy (2016), na sprawdzenie ewentualnych różnic międzypłciowych we wpływie warunków eksperymentalnych na wykonanie testów mentalizacyjnych. Należy jednak zauważyć, że czynnik płci był kontrolowany w badaniu Kidda i Castano (2013) oraz badaniach replikacyjnych i nie wykazały one, aby płeć w istotny sposób modyfikowała uzyskane wyniki. Niemniej w badaniach tych nie stosowano miar mentalizacji spontanicznej, w związku z czym w przyszłych badaniach z wykorzystaniem tej miary warto byłoby zrównoważyć liczbę uczestników płci męskiej i żeńskiej.

$\mathrm{Na}$ koniec należy również zauważyć, że eksplorując związki między zdolnościami mentalizacji a praktykami korzystania $\mathrm{z}$ mediów, skoncentrowaliśmy się na takich mediach, jak książka, prasa i telewizja. Wprawdzie zastosowany kwestionariusz pokazał, że uczestnicy naszego badania nie są w większości osobami, które nie oglądają telewizji, to jednak nie pytaliśmy ich o to, jak często i w jakim celu wykorzystują również inne medium współczesnego świata, jakim jest internet. Zagadnienie to wykracza poza ramy tego badania, ale może stanowić jeden z kierunków dalszych badań.
Podsumowując, należy stwierdzić, że przeprowadzone badanie prowadzi do wniosku, iż krótkotrwała ekspozycja na fabularną prozę, to jest taka, która polega na jednorazowym kontakcie z utworem beletrystycznym, najlepiej o walorach literackich, nie facylituje $\mathrm{w}$ istotnym stopniu spontanicznej lub jawnej mentalizacji. Jednocześnie korelacyjna część badania sugeruje, że istotny wpływ na zdolności mentalizacyjne wywierają czynniki działające bardziej długotrwale, wyrażające się w znajomości beletrystyki oraz związane z ekspozycją na telewizję. To zaś pozwala przypuszczać, że u podstaw zjawiska ekspozycji na fabularną prozę leży więcej niż jeden mechanizm, związany nie tylko z wyobrażeniową symulacją. W związku z tym w przyszłych badaniach należałoby więcej uwagi poświęcić również innym procesom i mechanizmom, które mogą być odpowiedzialne za to zjawisko.

Chodzi tutaj o dwie kwestie. Po pierwsze o pozostałe komponenty procesu ,przenoszenia się" według koncepcji Melanie C. Green i Timothy'ego C. Brocka (2002) - poznawczy i emocjonalny. Być może lektura fabularnej prozy silniej stymuluje lub aktywuje zdolności mentalizacyjne, jeżeli proza ta nie tylko pobudza wyobraźnię czytelnika, ale również (1) pozwala mu identyfikować się z postaciami bohaterów, oraz (2) angażować się emocjonalnie w fikcyjny świat opowiadania. W związku z tym w przyszłych badaniach należałoby sprawdzić rolę opisanych komponentów procesu „przenoszenia się" w świat literackiej fikcji, manipulując na przykład czynnikami, które czynią łatwiejsze lub trudniejsze identyfikowanie się z bohaterami, albo poszukując osobowościowych czynników warunkujących skłonność do tego rodzaju zachowań.

Po drugie - w myśl podejścia procesualnego, przedstawionego w części wprowadzającej artykułu, innym ważnym mechanizmem leżącym u podstaw zjawiska ekspozycji na fabularną prozę może być wnioskowanie o stanach mentalnych doświadczanych przez bohaterów opowiadania. W utworach beletrystycznych o walorach literackich stany te nie są zazwyczaj opisywane wprost, lecz muszą zostać wywnioskowane na podstawie takich wskazówek, jak wypowiedzi 
i zachowania bohaterów. To sprawia, że lektura tego rodzaju utworów, w porównaniu z lekturą literatury popularnej, może stanowić swego rodzaju trening zdolności mentalizacyjnych. Ponieważ jest raczej wątpliwe, aby krótkotrwały, jednorazowy kontakt z literacką prozą był wystarczający, aby w zauważalnym stopniu podnieść umiejętności wnioskowania o stanach mentalnych, rola tych procesów wydaje się ważniejsza w przypadku długotrwałej, powtarzającej się ekspozycji na fabularną prozę. W związku $\mathrm{z}$ tym $\mathrm{w}$ przyszłych badaniach warto byłoby sprawdzić, który z czynników w tego rodzaju treningu jest ważniejszy: treść opowiadania zachęcająca do refleksji nad pobudkami ludzkich zachowań czy też sposób przekazywania tych treści - werbalny lub obrazowy. Poznanie roli wymienionych wyżej czynników jest ważne również dlatego, że może pozwolić na lepsze zrozumienie zarówno mechanizmów, za pomocą których literatura beletrystyczna oddziałuje na ludzkie zdolności poznawcze, jak i tego, dlaczego słuchanie lub lektura opowieści jest czymś, co pociąga ludzi od tysięcy lat.

\section{PRZYPISY}

1 Należy zauważyć, że w nurcie badań nad mentalizacją wykorzystuje się wiele różnych miar mentalizacji spontanicznej, odnoszących się do poszczególnych mechanizmów i procesów. Dodell-Feder i wsp. (2013) nie precyzują, jakie procesy lub mechanizmy, postulowane przez różne koncepcje teorii umysłu, miałyby leżeć u podstaw proponowanego przez nich wskaźnika. Można przypuszczać, że nie są to te same procesy, które leżą u podstaw np. antycypacyjnych reakcji wzrokowych (np. Clements, Perner, 1994). Szersza dyskusja tego zagadnienia wykracza poza ramy tego artykułu.

2 Badania pokazują (por. np. Levin, Divine-Hawkins, 1974), że tworzenie wyobrażeń wzrokowych związanych z prezentowanym przekazem werbalnym jest skuteczniejsze, gdy przekaz ten prezentowany jest słuchowo niż wzrokowo. Tłumaczy się to tym, że percepcja słuchowa nie angażuje tych samych struktur mózgu, tj. kory wzrokowej, które angażują zarówno percepcja wzrokowa (czytanie tekstu), jak i tworzenie wyobrażeń wzrokowych (np. Paivio, 1971; Dijkstra, Bosch, van Gerven, 2019).

3 Polska adaptacja zadania Krótkie opowiadanie dostępna jest na żądanie u autorów pracy.

$4 \quad$ W przeprowadzonych dotąd badaniach nad zjawiskiem ekspozycji na fabularną prozę ich uczestnicy zapoznawali się z opowiadaniem, czytając je i nie odpowiadając na pytania kontrolne, sprawdzające zapamiętanie treści opowiadania. W związku z tym, aby zachować porównywalność procedury obecnego badania do tych wcześniejszych, również uczestnicy tych grup w obecnym badaniu, którzy czytali opowiadanie, nie odpowiadali na pytania kontrolne. Brak stosowania tego rodzaju pytań wynika z faktu, że przy losowym doborze osób do poszczególnych grup oraz takiej samej procedurze badania zakłada się, iż każda grupa będzie w takim samym stopniu podlegać wpływowi zmiennych niezależnych ubocznych (np. zakłóceniom uwagi podczas czytania tekstu). Ponieważ jednak w obecnym badaniu jedna z grup zapoznawała się z opowiadaniem w inny sposób niż pozostałe, słuchając go, zamiast czytać, uznaliśmy za konieczne sprawdzenie, czy uczestnicy tej grupy uważnie podążali za przekazem i zapamiętali najważniejsze wydarzenia opisane w opowiadaniu.

$5 \quad$ Należy zauważyć, że chociaż terminy „widzieć”, „być zdania” i „,dowiedzieć się”, występujące w pytaniach sprawdzających zapamiętanie treści opowiadania, można zaliczyć do kategorii terminów mentalnych, to pytania, w których zostały użyte, nie wymagały wnioskowania o stanach mentalnych, lecz jedynie przywołania z pamięci informacji zawartej w opowiadaniu. $\mathrm{W}$ opowiadaniu tym przedstawiane są bowiem wypowiedzi kilku osób na temat zdarzenia, którego były świadkami. Kluczową informacją w opowiadaniu jest zatem to, co ktoś widział, co powiedział i czego ewentualnie dowiedział się od innej osoby. Pytania takie należy odróżnić od pytań typu „dlaczego”, które mogą nie zawierać terminu mentalnego, a mimo to wymagać wnioskowania o stanach mentalnych. Są to np. pytania typu „Dlaczego ona to powiedziała?” w teście Dziwne historie (por. Happé, 1994). Aby jednak sprawdzić, czy użycie ww. terminów w pytaniach kontrolnych mogło wpłynąć na wyniki w zakresie mentalizacji spontanicznej, dokonaliśmy przeglądu wypowiedzi uczestników badania, które posłużyły do obliczenia wskaźnika mentalizacji spontanicznej. Analiza ta nie wykazała ani jednego przypadku użycia w tych wypowiedziach terminów „,widzieć” lub „być zdania” 
w grupie, która słuchała opowiadania i wypełniała ankietę. Terminy te nie pojawiły się zresztą w żadnej z pozostałych grup biorących udział w badaniu. Jedynie termin „dowiedzieć się” wystąpił w wypowiedzi jednej osoby $\mathrm{w}$ grupie słuchającej opowiadania, ale razem $\mathrm{z}$ innymi terminami mentalnymi, różnymi od ww., więc jego pojawienie się nie miało znaczenia dla wyniku tej osoby w zakresie mentalizacji spontanicznej, wynik ten bowiem przyjmuje wartość 1 już w przypadku wystąpienia chociażby jednego terminu mentalnego. Te dane sugerują, że użycie terminów mentalnych w niektórych pytaniach kontrolnych nie miało istotnego wpływu na wyniki w testach mentalizacji (por. również przedstawione w „Analizie wstępnej” wyniki analizy korelacji między poprawnością odpowiedzi na pytania kontrolne a wszystkimi wskaźnikami mentalizacji). Warto zauważyć, że termin „widzieć” i inne terminy mentalne są używane w pytaniach kontrolnych testów teorii umysłu, np. w testach fałszywych przekonań I i II rzędu. Na przykład w teście I rzędu jedno z pytań kontrolnych ma postać następującą: Czy X widział, jak Y przeniósł P z miejsca A do B? Tak więc nie sama obecność terminu mentalnego w pytaniu, lecz to, czego wymaga odpowiedź na pytanie, jest istotne dla uznania pytania za kontrolne lub testowe.

$6 \quad$ Rozkład wielkości grup, w których prowadzono badanie (od 2 do 5 osób), był podobny w każdym z czterech warunków eksperymentalnych, w związku z czym można założyć, że wpływ wielkości grupy na wykonanie zadań był taki sam w każdym warunku.

\section{BIBLIOGRAFIA}

Acheson D.J., Wells J.B., MacDonald M.C. (2008), New and Updated Tests of Print Exposure and Reading Abilities in College Students. Behavior Research Methods, 40, 278-289.

Baron-Cohen S. (1995), Mindblindness: An essay on Autism and Theory of Mind. Cambridge, MA: MIT Press. Baron-Cohen S., Wheelwright S., Jolliffe T. (1997), Is there a "Language of the Eyes"? Evidence from Normal Adults and Adults with Autism or Asperger Syndrome. Visual Cognition, 4, 311-331.

Baron-Cohen S., Wheelwright S., Hill J., Raste Y., Plumb I. (2001), The „Reading the Mind in the Eyes” Test Revised Version: A Study with Normal Adults, and Adults with Asperger Syndrome or High-Functioning Autism. Journal of Child Psychology and Psychiatry, 42, 241-251.

Barthes R. (1999 [1970]), S/Z, tłum. M.P. Markowski, M. Gołębiewska. Warszawa: Wydawnictwo KR.

Black J.E., Barnes J.L. (2015), The Effects of Reading Material on Social and Non-Social Cognition. Poetics, 52, 32-43.

Clements W.A., Perner J. (1994), Implicit Understanding of Belief. Cognitive Development, 9, 377-395.

Converse B.A., Lin S., Keysar B., Epley N. (2008), In the Mood to Get Over Yourself: Mood Affects Theoryof-Mind Use. Emotion, 8, 725-730.

DeLillo D. (2013 [2011]), Anioł Esmeralda. Dziewięć opowiadań, tłum. K. Obłucki. Warszawa: Oficyna Literacka Noir sur Blanc .

Dijkstra N., Bosch S.E., Gerven M.A.J. van (2019), Shared Neural Mechanisms of Visual Perception and Imagery. Trends in Cognitive Sciences, 23(5), 423-434.

Dodell-Feder D., Lincoln S.H., Coulson J.P., Hooker C.I. (2013), Using Fiction to Assess Mental State Understanding: A New Task for Assessing Theory of Mind in Adults. PLoS ONE, 8(11).

Forster E.M. (1927), Aspects of the Novel. London: Edward Arnold \& Company.

Green M.C., Brock T.C. (2000), The Role of Transportation in the Persuasiveness of Public Narratives. Journal of Personality and Social Psychology, 79(5), 701-721.

Green M.C., Brock T.C. (2002), In the Mind's Eye: Transportation-Imagery Model of Narrative Persuasion. W: M.C. Green, J.J. Strange, T.C. Brock (red.), Narrative Impact: Social Cognitive Foundations, 315-341. Mahwah, NJ: Erlbaum.

Happé F. (1994), An Advanced Test of Theory of Mind: Understanding of Story Characters' Thoughts and Feelings by Able Autistic, Mentally Handicapped, and Normal Children and Adults. Journal of Autism and Developmental Disorders, 24, 129-154.

Harris P.L. (2005), Conversation, Pretense, and Theory of Mind. W: J.W. Astington, J.A. Baird (red.), Why Language Matters for Theory of Mind, 70-83. Oxford: Oxford University Press.

Hemingway E. (1963 [1930]), Rzeka dwóch serc i inne opowiadania, tłum. B. Zieliński. Warszawa: Państwowy Instytut Wydawniczy. 
Kidd D.C., Castano E. (2013), Reading Literary Fiction Improves Theory of Mind. Science, 342, 377-380.

Kidd D.C., Castano E. (2017a), Different Stories: How Levels of Familiarity with Literary and Genre Fiction Relate to Mentalizing. Psychology of Aesthetics, Creativity, and the Arts, 11(4), 474-486.

Kidd D.C., Castano E. (2017b), Panero et al. (2016): Failure to Replicate Methods Caused the Failure to Replicate Results. Journal of Personality and Social Psychology, 112(3), e1-e4.

Kidd D.C., Ongis M., Castano E. (2016), On Literary Fiction and Its Effects on Theory of Mind. Scientific Study of Literature, 6(1), 42-58.

Levin J.R., Divine-Hawkins P. (1974), Visual Imagery as a Prose-Learning Process. Journal of Reading Behavior, 6(1), 23-30.

Mar R.A., Oatley K. (2008), The Function of Fiction is the Abstraction and Simulation of Social Experience. Perspectives on Psychological Science, 3, 173-192.

Mar R.A., Tackett J.L., Moore C. (2010), Exposure to Media and Theory-of-Mind Development in Preschoolers. Cognitive Development, 25, 69-78.

Nathanson A.I., Sharp M.L., Aladé F., Rasmussen E.E., Christy K. (2013), The Relation between Television Exposure and Theory of Mind Among Preschoolers. Journal of Communication, 63, 1088-1108.

Nowicki S. (2010), Manual for the Receptive Tests of the Diagnostic Analysis of Nonverbal Accuracy 2. Atlanta, GA: Emory University, Department of Psychology.

Oatley K. (2016), Fiction: Simulation of Social Worlds. Trends in Cognitive Sciences, 20(8), 618-628.

Paivio A. (1971), Imagery and Verbal Processes. New York: Holt.

Panero M.E., Weisberg D.S., Black J., Goldstein T.R., Barnes J.L., Brownell H., Winner E. (2016), Does Reading a Single Passage of Literary Fiction Really Improve Theory of Mind? An Attempt at Replication. Journal of Personality and Social Psychology, 111(3), 46-54.

Panero M.E., Weisberg D.S., Black J., Goldstein T.R., Barnes J.L., Brownell H., Winner E. (2017), No Support for the Claim That Literary Fiction Uniquely and Immediately Improves Theory of Mind: A Reply to Kidd and Castano's Commentary on Panero et al. (2016). Journal of Personality and Social Psychology, 112(3), e5-e8.

Perner J. (1991), Understanding the Representational Mind. Cambridge, MA: MIT Press.

Pino M.C., Mazza M. (2016), The Use of „Literary Fiction” to Promote Mentalizing Ability. PLoS ONE, 11(8). Rynkiewicz A., Ptaszek K. (2013), ,, Odczytywanie stanów umysłu na podstawie oczu” w wersji dla dorostych. Gdańsk: Centrum Diagnozy, Terapii i Edukacji Spectrum ASC-Med i Uniwersytet Gdański, Wydział Biologii.

Samur D., Tops M., Koole S.L. (2018), Does a Single Session of Reading Literary Fiction Prime Enhanced Mentalising Performance? Four Replication Experiments of Kidd and Castano (2013). Cognition and Emotion, 32(1), 130-144.

Senju A., Southgate V., White S., Frith U. (2009), Mindblind Eyes: An Absence of Spontaneous Theory of Mind in Asperger Syndrome. Science, 325, 883-885.

Shamay-Tsoory S.G., Aharon-Peretz J. (2007), Dissociable Prefrontal Networks for Cognitive and Affective Theory of Mind: A Lesion Study. Neuropsychologia, 45, 3054-3067.

Stanovich K.E., West R.F. (1989), Exposure to Print and Orthographic Processing. Reading Research Quarterly, 24(4), 402-433.

Steel D. (2012), Grzechy matki, thum. E. Spirydowicz, M. Kittel. Warszawa: Wydawnictwo Amber.

Tager-Flusberg H., Sullivan K. (2000), A Componential View of Theory of Mind: Evidence from Williams Syndrome. Cognition, 76, 59-89. 


\section{ZAŁĄCZNIK 1}

Streszczenie opowiadania „Biegacz” i pytania, na które odpowiadali uczestnicy grupy słuchającej opowiadania $\mathrm{w}$ ankiecie sprawdzającej zapamiętanie jego treści.

Główny bohater opowiadania, młody mężczyzna, uprawia jogging w parku. W pewnym momencie mężczyzna zauważa, że osoby znajdujące się w parku są poruszone jakimś zdarzeniem. Okazuje się, że uprowadzone zostało dziecko, które przebywało w parku z matką. Świadkami zdarzenia jest kilka osób, m.in. kobieta, z którą główny bohater rozmawia o tym, co się wydarzyło. Oboje zastanawiają się, kim był mężczyzna, który uprowadził dziecko. Po rozmowie z kobietą biegacz rozmawia z jeszcze jedną osobą, przybyłym na miejsce policjantem, od którego dowiaduje się, co powiedziała na temat zdarzenia matka dziecka.

Pytania:

1. Czy biegacz widział, jak mężczyzna, który wysiadł z samochodu w parku, zabrał chłopca?

2. Czy kobieta, z którą rozmawiał biegacz, widziała, jak mężczyzna, który wysiadł z samochodu w parku, zabrał dziecko?

3. Czy zdaniem tej kobiety mężczyzna, który zabrał chłopca, był jego ojcem?

4. Czego dowiedział się biegacz od policjanta?

5. Co powiedział biegacz kobiecie, z którą wcześniej rozmawiał, gdy spotkał ją ponownie przed kamienicą? 